\title{
ESTUDIO DE LOS LÍMITES DEL DERECHO A INTÉRPRETE Y A LA TRADUCCIÓN DE LOS DOCUMENTOS ESENCIALES EN LOS PROCESOS PENALES EN LA UE
}

\author{
BEGOÑA VIDAL FERNÁNDEZ' \\ Universidad de Valladolid \\ begoña.vidal@uva.es
}

Cómo citar/Citation

Vidal Fernández, B. (2018).

Estudio de los límites del derecho a intérprete y a la traducción de los documentos esenciales en los procesos penales en la UE. Revista de Derecho Comunitario Europeo, 60, 601-637. doi: https://doi.org/10.18042/cepc/rdce.60.04

\section{Resumen}

El presente estudio aborda el alcance, y en consecuencia los límites, del derecho a intérprete y a la traducción de los documentos esenciales de todo sospechoso o acusado en un proceso penal en la Unión Europea, así como de las personas buscadas por una orden europea de detención, según van siendo definidos por el Tribunal de

1 Profesora titular de Derecho Procesal y miembro del Instituto de Estudios Europeos de la Universidad de Valladolid. Trabajo realizado en el marco del proyecto de investigación DER2015-71418-P («Un paso adelante en la consolidación del Espacio Judicial Europeo y su aplicación práctica en España: visión desde el proceso civil y penal», investigador principal: M. Jimeno Bulnes), así como del proyecto de investigación DER2016-78096-P ("Garantías procesales de investigados y acusados: la necesidad de armonización y fortalecimiento en el ámbito Unión Europea», investigadoras principales: C. Arangüena Fanego y M. De Hoyos Sancho). 
Justicia a través de su jurisprudencia. El Tribunal de Justicia ha clarificado el ámbito material de aplicación de estos derechos poniendo la frontera en la resolución del juez penal sobre la responsabilidad criminal del acusado, si bien ha dejado abierta la posibilidad de una extensión de estos derechos más allá, a través del juego de la cláusula de no regresión aplicada a la interpretación que los Estados puedan hacer de expresiones como «documentos esenciales». Se analiza asimismo la actuación del Tribunal Supremo español, que ha asumido ya su papel de supremo intérprete de la legalidad ordinaria en relación con estos derechos, revelando los aspectos menos satisfactorios de las modificaciones de la legislación procesal española que la implementación de la directiva ha provocado.

\title{
Palabras clave
}

Derecho a traducción; derecho a intérprete; garantías procesales; procesos penales; sospechoso; acusado; persona buscada.

\section{STUDY ABOUT THE LIMITS OF THE RIGHT TO INTERPRETATION AND TRANSLATION OF ESSENTIAL DOCUMENTS ON CRIMINAL PROCEEDINGS IN THE EU}

\begin{abstract}
This study deals with the scope, and therefore the limits, of the rights to interpretation and translation of essential documents in criminal proceedings, that belong to any suspect or accused person in criminal proceedings in the European Union, as well as to any requested person in proceedings for the execution of an European Arrest Warrant, as they are being defined by the European Court of Justice's case-law. The European Court has clarified the objective scope of these rights by putting the border on the Criminal Court's decision over the accused person's criminal responsibility. Nevertheless, a possibility is left to an extension of these rights beyond this limit, by means of the non-regression clause, applied to the interpretation made by Member States of expressions such as "essential documents". An analysis is also made of how Spanish Supreme Court (Tribunal Supremo) has assumed its role as supreme interpreter of the ordinary legislation concerning these rights, and how its action has exposed the less satisfying points of the Spanish procedural regulation modification's required by the Directive's implementation.
\end{abstract}

\section{Keywords}

Right to translation; right to interpretation; procedural guarantees; criminal proceedings; suspect person; accused person; requested person. 


\section{ÉTUDE SUR LES LIMITES DU DROIT À L'INTERPRÉTATION ET À LA TRADUCTION DES DOCUMENTS ESSENTIELS DANS LES PROCÉDURES PENALES DANS L'UE}

\section{Résumé}

Cet article aborde la portée, donc les limites, du droit à l'interprétation et du droit à la traduction des documents essentiels, de tout suspect et de toute personne poursuivie dans une procédure pénale dans l'Union européenne, du même que des personnes recherchées en exécution d'un mandat d'arrêt européen, selon la définition de la jurisprudence de la Cour de justice. La Cour de justice a clarifié le champ matériel d'application de ces droits en plaçant la frontière dans la décision du juge pénal sur la responsabilité pénale de la personne poursuivie. Néanmoins, la Cour de justice a laissé la possibilité ouverte d'une extension de ces droits au-delà de cette limite, par moyen de la clause de non-régression appliquée à l'interprétation à faire par les autorités nationales de termes tels que "documents essentiels". Il analyse aussi la façon dont la Cour suprême espagnole (Tribunal Supremo) agit dans son rôle d'interprète ultime de la légalité ordinaire, en montrant ainsi les aspects les moins satisfaisants des modifications effectuées dans la législation procédurale espagnole à conséquence de la transposition de la directive.

\section{Mots clés}

Droit à la traduction; droit à l'interprétation; garanties procédurales; procédures pénales; suspect; personne poursuivie; personne recherchée. 


\section{SUMARIO}

I. FUNDAMENTO DEL DERECHO A INTÉRPRETE Y A TRADUCCIÓN EN LA UE. II. SUJETOS TITULARES DE ESTOS DERECHOS. III. ÁMBITO OBJETIVO DE APLICACIÓN DE LOS DERECHOS: «PROCESO PENAL». IV. DERECHO A INTÉRPRETE: CONSECUENCIAS DE SU ÍNTIMA VINCULACIÓN CON EL DERECHO FUNDAMENTAL DE DEFENSA. V. DERECHO A LA TRADUCCIÓN DE DOCUMENTOS ESENCIALES: 1. Significado y límites de la expresión «documentos esenciales». 2. Alcance del derecho a traducción gratuita. VI. CONSIDERACIONES FINALES. BIBLIOGRAFía.

\section{FUNDAMENTO DEL DERECHO A INTÉRPRETE Y A TRADUCCIÓN EN LA UE}

Es posible encontrar ejemplos remotos de la necesidad de reconocer este derecho en la historia de la integración europea, pues lo que ahora reconocemos sin ningún género de duda como un derecho fundamental, integrado en el esencial derecho de defensa de todo proceso equitativo o con todas las garantías, había aparecido con anterioridad como manifestación del principio de igualdad de todos los ciudadanos europeos, que prohíbe toda discriminación por nacionalidad y que está en la base del fenómeno comunitario. En 1998, el entonces Tribunal de Justicia de las Comunidades Europeas resolvió una cuestión prejudicial vinculando el derecho del encausado en un proceso penal a entender lo que está sucediendo con el principio de no discriminación por razón de la nacionalidad en su respuesta a la pregunta: «¿Puede un nacional de un Estado miembro invocar el principio de no discriminación por razón de la nacionalidad para que se le conceda el derecho a que un proceso penal incoado en su contra en otro Estado miembro se desarrolle en una lengua distinta de la lengua oficial de dicho Estado cuando algunos nacionales de este último Estado miembro gozan de dicho derecho?»².

2 Sentencia del Tribunal de Justicia de 24 de noviembre de 1998, Bickel y Franz, C-274/96, EU:C:1998:563. Conclusiones del abogado general Jacobs, Bickel y Franz, C-274/96, EU:C:1998:115. En este supuesto coincidían dos acusados: Bickel —austriaco-y Franz —alemán_, encausados en sendos procesos penales ante el mismo juez de la región italiana de Bolzano, donde reside una importante minoría de germano-parlantes, por lo que se les permite optar por este idioma cuando han de litigar. Se 
La evolución de la integración europea ha arrastrado el progresivo reconocimiento de derechos fundamentales cuya positivación al más alto nivel ha culminado en la Carta de Derechos Fundamentales de la Unión Europea (CDFUE). La concreción de estos derechos fundamentales ha desencadenado una actividad normadora en todos los ámbitos. Especialmente sensible es el campo del proceso penal, donde aquel derecho a elegir la lengua, que le permite entender el proceso en igualdad de condiciones con los nacionales residentes en el lugar del tribunal, no debe ser considerado aisladamente, sino como una garantía esencial en el contexto de los derechos de la defensa que integran el concepto de proceso equitativo o con todas las garantías. El derecho a la interpretación y a la traducción de calidad en los procesos penales es un derecho esencial que nace de la necesidad derivada de las limitaciones lingüísticas de los individuos, haciendo posible el ejercicio de otros derechos como el derecho a asistencia jurídica gratuita o a recibir información sobre los derechos propios. En palabras de Guerrero Palomares (2016: 2), «quien no entiende idiomáticamente los hechos que se le atribuyen, el estadio procesal en el que se encuentra ni los derechos que le protegen, no puede alegar en su defensa, ni proponer prueba sobre los mismos, ni contradecir aquello que exista en su contra. No cabe indefensión más mayúscula». Planteada en el seno de la Unión Europea (UE) la necesidad de armonizar las garantías procesales de todo encausado, se alcanzó un acuerdo en esta materia en primer lugar por dos motivos: porque existía ya un gran consenso entre los Estados ${ }^{3}$ y porque si la sociedad actual se caracteriza por la globalización, la Unión Europea lo ha sido desde sus comienzos por el respeto a la diversidad de los pueblos que la integran, sus culturas, tradiciones y lenguas. Puede afirmarse que el multilingüismo es una nota esencial del fenómeno

planteaba la cuestión de si el derecho comunitario exigía la extensión de esta facultad de opción a todo ciudadano europeo de lengua alemana ante estos tribunales. El Tribunal de Justicia efectivamente lo extendió argumentando que adoptar cualquier otra decisión hubiera supuesto reconocer la posibilidad de una diferenciación basada en la nacionalidad de los justiciables, lo que es absolutamente contrario al derecho comunitario europeo.

3 Teniendo en cuenta la desconfianza permanente de algunos Estados centroeuropeos hacia la mayoría del resto de los sistemas procesales penales, estos Estados tan renuentes al reconocimiento mutuo de resoluciones penales sin embargo estaban completamente a favor de que se garantizara a sus ciudadanos la asistencia de alguien que les facilitase la comunicación en otro Estado, para hacerse entender y para entender lo que está ocurriendo. 
comunitario $^{4}$ que incluso ha sido reconocido como un derecho fundamental del que también son titulares los Estados miembros (Platon, 2016)

Con este viento favorable, el 20 de octubre de 2010 se aprobó la Directiva 2010/64//UE del Parlamento Europeo (PE) y del Consejo relativa al derecho a interpretación y a traducción en los procesos penales ${ }^{6}$. La elección de una directiva como instrumento legislativo vino obligada por la entrada en vigor del Tratado de Lisboa, el 1 de diciembre de 2009, que supuso la comunitarización de la materia de cooperación judicial penal ${ }^{7}$.

Sus disposiciones se fundamentan en el Convenio Europeo de Derechos Humanos (CEDH) interpretado por la jurisprudencia del Tribunal Europeo de Derechos Humanos $(\mathrm{TEDH})^{8}$, de tal modo que ha incorporado dicha

4 Prácticamente todos los Estados miembros de la UE se han convertido en sociedades multilingües y multiculturales. El folleto editado por la Dirección General de Interpretación de la Comisión Europea en 2017, Interpretar y traducir para Europa, elaborado por el Comité Interinstitucional de Traducción e Interpretación, es muy ilustrativo de las necesidades de traducción y de intérpretes que deriva de este multilingüismo. Actualmente se hablan y se utilizan al menos 450 lenguas diferentes en los territorios de los Estados miembros. El respeto por la multitud de lenguas que conviven en el territorio de la Unión Europea ha sido una seña de identidad comunitaria desde los Tratados de Roma, si bien únicamente alcanzó la categoría de «área política de la Unión» a partir del 1 de enero de 2007, cuando se creó una cartera separada de la Comisión. A partir de dicho año se abrió al público la base de datos terminológica IATE (Inter-Active Terminology for Europe), con más de 8 millones de términos, que reúne todos los recursos terminológicos de los servicios de traducción de la UE. Además, las instituciones de la UE poseen mayor cantidad de textos multilingües que ninguna otra organización como consecuencia de la oficialidad de 23 lenguas en la Unión. Para facilitar su consulta existe una base interinstitucional de memorias de traducción de la UE: Euramis.

5 Platon lo encuadra en el art. 22 CDFUE: la Unión respeta la diversidad cultural, religiosa y lingüística, y recuerda a modo de fundamento para su argumento la sentencia del Tribunal de Justicia de 5 de mayo de 2015, España/Comisión, C-147/13, EU:C:2015:299, en relación con el Reglamento sobre las modalidades de traducción de la patente europea. Gardete (2016: 345-354) también trata el tema del multilingüismo y su vinculación con el derecho de acceso a la jurisdicción en la propia lengua.

6 DO L 280 de 26 de octubre de 2010. Realizan un detenido estudio de la génesis de la directiva Cras y De Matteis (2010: 153-162). Sobre el instrumento que la precedió y la iniciativa de directiva, véase Vidal Fernández (2010: 183-222).

7 Sobre el profundo significado de regular comunitariamente una materia mediante directiva en cuanto norma de armonización, véase Faggiani (2017).

8 Durante las discusiones en el Consejo de Justicia y Asuntos de Interior del borrador, Eslovenia sugirió someter el texto a la Secretaría del Consejo de Europa para que 


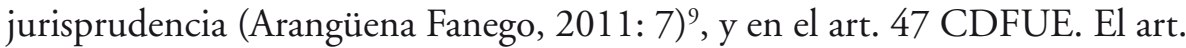
$6 \mathrm{CEDH}$ positiviza las garantías y derechos fundamentales procesales comunes en Europa, articulados en tres apartados: acceso a la jurisdicción en un proceso equitativo, presunción de inocencia y por último los derechos de la defensa. Este precepto, interpretado por el TEDH, ha constituido un punto de referencia constante para el Tribunal de Justicia de la UE (TJUE) en la formación de un sistema europeo de justicia penal (Faggiani, 2017: 35-36). El derecho a un intérprete como manifestación concreta del derecho fundamental a un proceso con todas las garantías está contemplado en prácticamente todas las Cartas Constitucionales de los Estados modernos, y en los más importantes textos internacionales en esta materia ${ }^{10}$. En cambio, la consideración del derecho a traducción como derecho fundamental es obra del $\mathrm{TEDH}^{11}$, que ha ido elaborando "categorías autónomas» que integran un mínimo común, con un significado que es independiente del que pueden tener en los ordenamientos nacionales y que conceden a los Estados parte la flexibilidad

verificara si era conforme con el Convenio y con la jurisprudencia del TEDH. Realizadas consultas informales por la presidencia sueca, se obtuvieron como respuesta opiniones positivas sobre la iniciativa [véase el documento del Consejo de la UE de 21 de octubre de 2009, DROIPEN 125, COPEN 197, Expediente Interinstitucional: 2009/0101 (CNS), p. 3].

9 Véase asimismo Arangüena Fanego (2015: 267-316).

10 Así es considerado por las Constituciones de todos los Estados miembros de la Unión Europea. En cuanto a los textos internacionales, véase la exhaustiva enumeración que realiza Vanden Bosch (2003).

11 En su sentencia de 19 de diciembre de 1989, Kamasinski c. Austria, CE:ECHR:1989:1219JUD000978382, apdo. 74 declara: «El derecho establecido en el apartado 3.e) del artículo 6, de ser asistido gratuitamente por un intérprete no solo se aplica a las declaraciones orales en el juicio, sino también a todos los documentos escritos y a la instrucción preparatoria. Quiere decir el apartado que el acusado que no comprenda o no hable la lengua utilizada en el proceso, tiene derecho a los servicios gratuitos de un intérprete que le traduzca o interprete cualquier acto... cuyo sentido necesite conocer para contar con un proceso justo». Y en el apdo. 79 aclara: «Aunque (el apartado 3.a) del art. 6) no especifica que se deba facilitar o traducir por escrito a un inculpado extranjero la pertinente información [...] El acta de acusación juega un papel decisivo en las actuaciones penales [...] Un acusado que desconozca la lengua utilizada por el tribunal puede encontrarse de hecho en una situación desfavorable si no se le entrega también una traducción del acta de acusación escrita en un idioma que comprenda». El TEDH reitera esta jurisprudencia en pronunciamientos posteriores (véase la sentencia del TEDH de 18 de octubre de 2006, Hermi c. Italia, CE:ECHR:2006:1018JUD001811402, apdos. 68 y 69). 
necesaria para concordar sus ordenamientos internos con este mínimo común (Faggiani, 2017: 54) ${ }^{12}$.

Tras la entrada en vigor de la CDFUE, la influencia del TEDH sobre el Tribunal de Justicia (TJ) se ha visto facilitada por su giro hacia este órgano reconociéndole una "presunción de tutela equivalente» (Faggiani, 2017: 79) de los derechos fundamentales por medio de los instrumentos procesales del derecho de la Unión Europea (Faggiani, 2017: 75-76) ${ }^{13}$. A partir de este reconocimiento, los derechos de la defensa recogidos en los arts. 47 y 48 CDFUE pasan a definirse en atención al alcance que les da el CEDH, conforme predica el art. 53.2 de la propia Carta, pero con un contenido referido a los derechos y libertades garantizados por el derecho de la UE (Faggiani, 2017: 80).

La directiva se desarrolla en doce artículos ${ }^{14}$, en los que se regulan aspectos de esta actividad de asistencia técnico-lingüística en que consiste la traducción y la interpretación judiciales, prestadas en el marco de un proceso penal. El contenido de la directiva ha sido implementado a la legislación procesal penal española mediante Ley Orgánica (LO) 5/2015, que ha introducido los nuevos arts. 123 a 127 en la Ley de Enjuiciamiento Criminal (LECrim) ${ }^{15}$.

\section{SUJETOS TITULARES DE ESTOS DERECHOS}

Desde un punto de vista subjetivo el art. 1 de la directiva hace nacer este derecho en todo sospechoso o acusado o persona detenida en virtud de una orden europea de detención. Se aplica a cualquier persona desde el momento en que es informada por las autoridades competentes de un Estado miembro (excepto en Dinamarca ${ }^{16}$ ) de que es sospechosa de haber cometido una

12 Donde la autora expone su concepción sobre la «tensión» latente entre ese mínimo estándar común de tutela y la autonomía estatal.

13 Faggiani utiliza como argumento la jurisprudencia del TEDH sobre el valor que otorga a la cuestión prejudicial al incluir la negativa no motivada a elevarla como un supuesto de vulneración del derecho a la tutela en su manifestación de derecho a la motivación de las resoluciones del art. 6.1 CEDH.

14 Precedidos de 38 considerandos a los que es necesario acudir para iluminar el sentido de este escueto articulado.

15 BOE núm. 101 de 28 de abril de 2015, pp. 36559 y ss. Realiza un estudio exhaustivo y muy ilustrativo de estos preceptos Guerrero Palomares (2016). Véase también López Jara (2015); Portal Manrubia (2016); y Fernández Carrón (2017: 73-154), que dedica un largo capítulo al estudio de esta normativa.

16 Sobre el ámbito de aplicación territorial de la directiva no se dice nada en el articulado, pero sí en los considerandos en los que se informa de que tanto Reino Unido 
infracción penal (es decir, desde el momento de su detención o cuando ya no se le permite sustraerse a la custodia policial) ${ }^{17}$. Por tanto es titular de estos derechos la persona a quien se impute un hecho punible, cualquiera que sea el procedimiento y desde que se le comunique su existencia, haya sido objeto de detención o de cualquier otra medida cautelar o se haya acordado su procesamiento ${ }^{18}$, y hasta la "resolución definitiva de la cuestión de si el sospechoso o acusado ha cometido o no la infracción», de acuerdo con el texto de la norma. A efectos de la titularidad de este derecho fundamental es indiscutible, en palabras de Arangüena Fanego (2017: 2), la equiparación entre nacionales y extranjeros, puesto que se trata de garantías que emanan de las "personas» como centros de imputación de derechos derivados de la dignidad humana, y no de "ciudadanos» miembros de una comunidad política, ni de «nacionales» titulares de la nacionalidad. Y en tanto no son excluidas, entiende De Hoyos Sancho (2017: 8-9) que asimismo son titulares las personas jurídicas, dado que también pueden ser investigadas y encausadas en un proceso penal ${ }^{19}$. Es un derecho universal cuyo reconocimiento únicamente requiere que la persona haya sido informada de su condición de sospechosa o acusada de haber cometido una infracción penal.

La directiva pone un límite, que es el efectivo desconocimiento de la lengua del proceso, y ello con independencia de la nacionalidad o la residencia, porque en caso contrario y aunque no sea su lengua materna, no nace el derecho a intérprete y a traducción ${ }^{20}$.

Por sospechoso "que no hable ni comprenda la lengua del proceso" se entiende también aquella persona con limitaciones auditivas o expresivas que le impidan participar activamente en el proceso. Así, la directiva incorpora en el art. 2.3 una especial consideración para los supuestos en los que la no comprensión viene dada por limitaciones auditivas o de comunicación, con

como Irlanda han notificado su deseo de participar, por lo que la directiva es aplicable en ambos territorios (considerando 35). Dinamarca, en cambio, no lo ha hecho, por lo que no se le aplica ni está vinculada por la directiva (considerando 36).

17 Trata este punto de manera detallada Alvarez de Neyra Kappler (2018: 63-88).

18 En coherencia se ha reformado el art. 118 LECrim para incluir el «derecho a traducción e interpretación gratuitas» en la relación de derechos de los que tiene que ser informada sin demora toda persona sospechosa de haber cometido un hecho punible.

19 Específicamente afirma en la pág. 13: «[...] cuando la LECrim se refiere a los “imputados o acusados" - hoy investigados o encausados - engloba tanto a las personas físicas como a las jurídicas, pues una y otras pueden ser sujetos pasivos de un proceso penal, y por tanto han de estar incluidas en el ámbito de aplicación de estos preceptos que regulan garantías procesales».

20 En este sentido también Vieira Morante (2013) y Pardo Iranzo (2014: 385-402). 
relación al derecho a intérprete, e impone a las autoridades policiales, judiciales y a la fiscalía el deber de garantizarles el ejercicio de estos derechos mediante la adopción de las medidas más adecuadas ${ }^{21}$, como serán facilitar documentos en braille cuando la limitación sea visual, o intérpretes de lengua de signos en supuestos de limitación auditiva ${ }^{22}$. Es interesante la solución aplicada en Reino Unido, donde existe un registro de intermediarios (RIs) para asistir a las personas que han de declarar ante la policía o en los tribunales y que se encuentran en la situación de fragilidad señalada en la directiva, de modo que cuando el oficial o la autoridad se da cuenta de la vulnerabilidad del sospechoso o inculpado por razón de dificultades de comunicación, solicita la intervención de un intermediario registrado ${ }^{23}$.

La expresión «sospechoso o acusado» se interpreta a modo de expresión autónoma, independientemente de cómo se denominen en los procedimientos nacionales, pero en todo caso siempre ha de tratarse de supuestos en los que la decisión final la dicta un tribunal penal ${ }^{24}$.

21 Este deber está expresamente recogido en el considerando (27), en cuanto fundamento de una administración equitativa de justicia: «El deber de velar por los sospechosos o acusados que se encuentran en una posible posición de fragilidad, en particular debido a impedimentos físicos que afecten a su capacidad de comunicarse de manera efectiva, fundamenta la administración equitativa de justicia. Por tanto, la fiscalía y las autoridades policiales y judiciales deben garantizar que dichas personas puedan ejercer de manera efectiva los derechos que se establecen en la presente Directiva, por ejemplo teniendo en cuenta cualquier posible vulnerabilidad que afecte a su capacidad de seguir el procedimiento y de hacerse entender, y tomando las medidas necesarias para garantizar dichos derechos».

22 Con las dificultades que se añaden, pues el texto o el párrafo ha de ser traducido en signos con las modificaciones del mensaje que puede suponer. Sobre estos problemas y las situaciones legales en los Estados miembros, véase el informe de la Agencia Europea de Derechos Fundamentales (FRA, 2016: 92 y ss.).

23 Véase el Informe FRA (2016: 94).

24 El sistema penal español distingue varias figuras, matizando el concepto genérico de «sospechoso» o de «inculpado» (toda persona física contra quien se dirige un proceso penal, de acuerdo con la común definición recogida por Gómez Orbaneja [1981: 75]). La reforma operada en la LECrim por la LO 13/2015 ha sustituido la tradicional palabra «imputado» por la de «investigado». Como explica Armengot Vilaplana (2016), en la ley se prefiere llamar «investigado» a la persona sobre la que se centra la investigación por existir sospechas de su participación en el hecho delictivo, y se impone denominar «encausado» al sujeto respecto del cual se ha dictado una resolución judicial por la que se formaliza la imputación («imputado formal» en el procedimiento abreviado, art. 779.1.4. ${ }^{\circ}$ LECrim y "procesado» en el proceso ordinario, art. 384 LECrim), sin perjuicio de reconocer que «se mantienen los términos "acusado" 
También es titular del derecho a intérprete y a la traducción la persona buscada y detenida en virtud de una orden europea de detención y entrega (OED/OEDyE), en el Estado de ejecución de dicha orden ${ }^{25}$. La traducción ha de hacerse bien al idioma oficial del Estado de ejecución, bien al que dicho Estado haya manifestado aceptar ${ }^{26}$, y ha de realizarse utilizando el formulario normalizado de las $\mathrm{OED}^{27}$.

o "procesado", que podrán ser empleados de forma indistinta al de "encausado" en las fases oportunas». "Con la reforma de la LO 13/2015, tanto el sujeto respecto del cual se ha iniciado una investigación pre-procesal (por ejemplo por la fiscalía) como el sujeto que ha sido citado a declarar por el juez, pasan a denominarse "investigados". Se difumina, con esta denominación, la frontera que existía entre el investigado y el imputado, a menos que se utilice el término sospechoso para designar al investigado en la fase pre-procesal», además «el tránsito de la condición de investigado (por la policía o por el fiscal) a la de investigado judicial (anterior imputado) depende de una valoración jurisdiccional sobre la verosimilitud de la imputación; es decir, el juez no asume de manera automática la imputación que se desprende de una denuncia, de una querella, o de la investigación previa de la policía o del fiscal, sino que esos actos se someten a un juicio jurisdiccional sobre el carácter punible de los hechos y sobre la posibilidad de que los haya realizado una persona». Debe por tanto distinguirse entre el investigado sospechoso y el investigado judicial o antiguo imputado, y en este estadio ha de distinguirse entre investigado judicial y encausado (o imputado formal) a efectos de todas las garantías y derechos que corresponden a este último (Armengot Vilaplana, ibid.).

Para Calaza López (2016) deberían «mantenerse las expresiones siguientes: investigado/ sospechoso/ querellado/ denunciado (sujeto sobre el que pende una investigación preliminar), imputado (sujeto sobre el que ha recaído un primer acto formal de imputación), procesado (sujeto contra el que se ha dirigido el auto de procesamiento), acusado (sujeto contra el que se ha dirigido la acusación) y, al fin, condenado o absuelto (no precisa explicación por su obviedad)».

25 Con el mismo contenido que todo sospechoso o acusado: art.1.1, art.2.7 y art. 3.6, todos ellos de la Directiva 2010/64/UE. También se reconoce este derecho a toda persona reclamada en virtud de un procedimiento de extradición, como recogen los arts. 12 y 14 de la Ley 4/1985 de Extradición Pasiva. En el mismo sentido Fernández Carrón (2017: 46). Véase asimismo Valbuena González (2011: 201-229).

26 Los Estados miembros transmiten a la Comisión los idiomas en los que admiten la cumplimentación válida o la traducción de una OED. El listado de idiomas aceptados por los diversos Estados miembros se encuentra en la carpeta denominada Fichas belgas (Fiches belges) de la web de la Red Judicial Europea (RJE) en materia penal (www. ejn-crimjust.europa.eu).

27 Disponible también en la web de la RJE en materia penal (apartado: Biblioteca Judicial). 
En cambio ni esta Directiva ni la relativa a las garantías procesales de los menores ${ }^{28}$ mencionan el derecho de los menores sospechosos, acusados o detenidos a traducción o a intérprete ${ }^{29}$. Solamente por la vía indirecta de encontrarlo recogido dentro del derecho a la información ${ }^{30}$ y de la remisión que hace a ésta la Directiva de menores ${ }^{31}$, cabe interpretar que necesariamente han de ser aplicable a los menores los derechos regulados para los adultos.

\section{III. ÁMBITO OBJETIVO DE APLICACIÓN DE LOS DERECHOS: «PROCESO PENAL»}

La directiva es aplicable en los procesos penales ${ }^{32}$ y procedimientos de ejecución de una orden europea de detención ${ }^{33}$. Es importante esta precisión en relación con los casos de detención en aplicación de la euroorden (orden europea de detención y entrega) porque la decisión marco que la regula solamente se refiere a este derecho en términos muy generales, y porque en este sentido aparece la directiva como una nueva dimensión del art. $5 \mathrm{CEDH}$, ya que las detenciones que implican traslados en este marco no están expresamente incluidas en el supuesto previsto ${ }^{34}$. Se consagra el derecho de la persona buscada y detenida en ejecución de una euroorden a contar con un intérprete, pero siempre según el derecho interno del Estado miembro de ejecución. En consecuencia, si la detención se produce en España, la persona tiene derecho

28 Directiva 2016/800/UE relativa a las garantías procesales de los menores sospechosos o acusados en los procesos penales (DO L 132 de 21 de mayo de 2016).

29 En cambio la legislación española sí, por remisión del art. 17.1 de LO 5/2000, reguladora de la responsabilidad penal de los menores, al art. 520 LECrim, cuyo apdo. 2 letra h lo recoge para toda persona detenida o presa.

30 Art. 3.1.d) de la Directiva 2012/13/UE, relativa al derecho a la información en los procesos penales, DO L 142 de 1 de junio de 2012.

31 Art. 4.1 Directiva 2016/800/UE. Para un conocimiento completo de esta directiva véase el profundo estudio que realiza Serrano Masip (2016: 209-264).

32 Art. 1.2 Directiva 2010/64/UE.

33 Art. 1.1 Directiva 2010/64/UE.

34 Art. 5.2 CEDH: "Toda persona detenida preventivamente debe ser informada, en el más breve plazo y en una lengua que comprenda, de los motivos de su detención y de cualquier acusación formulada contra ella». Así está expresamente reconocido en el acto previo a la directiva presentado por la Comisión al Consejo: Propuesta de decisión marco del Consejo relativa al derecho a interpretación y a traducción en los procesos penales, de 2009 (SEC(2009)915, SEC(2009)916/COM/2009/0338 final-CNS 2009/0101, punto 15, párr. segundo). 
a ser asistida de intérprete cuando sea necesario a lo largo de las sucesivas incidencias que se produzcan ante las autoridades policiales y judiciales, según la normativa española aplicable ${ }^{35}$. Este derecho se materializa con la traducción del «mandamiento» de detención y entrega emitido por una autoridad judicial de la Unión Europea (Jiménez Villarejo, 2008: 495), y la presencia de un intérprete en todas las actuaciones ante la autoridad judicial, pues las decisiones expresadas por la persona buscada y detenida solamente son válidas si han sido adoptadas previo pleno asesoramiento de letrado y con presencia e intervención de intérprete cuando no conozca suficientemente la lengua del Estado de ejecución ${ }^{36}$. Se le ha de informar de ello en el momento de su detención ${ }^{37}$.

$\mathrm{Al}$ aludir expresamente a "procesos penales» la norma comunitaria quiere limitar su aplicación a los procedimientos desarrollados ante autoridades públicas que desemboquen en una resolución dictada por un tribunal competente en materia penal. Por tanto no es aplicable a las infracciones menores impuestas por una autoridad distinta de un tribunal penal ${ }^{38}$, sin perjuicio de

35 La regulación relativa a la OEDyE ha sido modificada al entrar en vigor la Ley 23/2014 de reconocimiento mutuo de resoluciones penales en la UE, cuyo art. 4.1 dispone: «El reconocimiento y la ejecución de los instrumentos de reconocimiento mutuo que se enumeran en el artículo 2, se regirán por lo dispuesto en esta Ley, en las normas de la Unión Europea y en los convenios internacionales vigentes en los que España sea parte. En defecto de disposiciones específicas, será de aplicación el régimen jurídico previsto por la Ley de Enjuiciamiento Criminal». Los arts. 50 y 51 de dicha ley regulan la detención y la audiencia al detenido ante el juez central de instrucción en el plazo máximo de setenta y dos horas desde la puesta a disposición, con asistencia del Ministerio Fiscal, del abogado de la persona detenida y, en su caso, de intérprete, debiendo realizarse conforme a lo previsto por la LECrim para la declaración del detenido. La LECrim contempla esta actuación para el juicio ordinario por delito en los arts. 398, 440 a 442, y 520.2.h): «Toda persona detenida o presa será informada por escrito, en un lenguaje sencillo y accesible, en una lengua que comprenda y de forma inmediata, de los hechos que se le atribuyan y las razones motivadoras de su privación de libertad, así como de los derechos que le asisten y especialmente de los siguientes: [...] h) Derecho a ser asistido gratuitamente por un intérprete, cuando se trate de extranjero que no comprenda o no hable el castellano o la lengua oficial de la actuación de que se trate, o de personas sordas o con discapacidad auditiva, así como de otras personas con dificultades del lenguaje». Para el proceso penal abreviado se recoge en el art. $762.8^{\text {a }}$ LECrim. Art. 51 de la Ley 23/2014 de reconocimiento mutuo de resoluciones penales.

37 Véase sobre estas actuaciones Jimeno Bulnes (2017: 35-76), quien con anterioridad ya había tratado esta materia. Véase también Ruz Gutiérrez (2017: 77-104).

El art. 1.3 Directiva 2010/64 establece este límite. La redacción de este precepto se entiende mejor a la luz del considerando (16): «En algunos Estados miembros una 
que sí que sea de aplicación en un ulterior procedimiento de recurso contra tal resolución ante un tribunal penal ${ }^{39}$.

El tenor de esta regulación plantea dos interrogantes cuya respuesta fija los límites objetivos de aplicación de la directiva en dos direcciones: 1) extensión (es aplicable hasta la resolución definitiva sobre la responsabilidad penal del sospechoso o acusado o persona reclamada), porque ¿qué ocurre cuándo finalizado el proceso penal es precisa una actuación posterior para hacer efectiva la decisión penal definitiva?, ¿es aplicable la directiva en esta actuación posterior pero íntimamente ligada al propio proceso finalizado?; y 2) naturaleza jurídica del procedimiento (no es aplicable a las infracciones menores impuestas por autoridad distinta de un tribunal penal), pues ¿qué ocurre si se adopta una decisión (que supone la imposición de una pena) mediante un procedimiento ante una autoridad distinta de un tribunal penal contra cuya resolución no cabe recurso?

Ambos interrogantes son reconducibles a una misma cuestión jurídica: la delimitación objetiva del ámbito de aplicación de la directiva, y en consecuencia saber qué ha de entenderse por "proceso penal» a efectos de la directiva. Por lo que respecta al aspecto procedimental, que en España sería el caso de una decisión adoptada en el procedimiento por aceptación de decreto ante el Ministerio Fiscal, la respuesta está vinculada a la interpretación dada por el TJ del carácter de documento esencial, o no, de la decisión que resuelve sobre la responsabilidad penal del acusado pero que no es dictada por un juez ${ }^{40}$. El ordenamiento español regula asimismo el procedimiento para poner a disposición del juez de guardia a los extranjeros ilegales ${ }^{41}$, detenidos durante la tramitación del expediente sancionador hasta la resolución del juez ordenando

autoridad distinta de un tribunal con competencia en materia penal es competente para imponer sanciones cuando se trata de infracciones relativamente menores. Ese puede ser el caso, por ejemplo, en relación con infracciones de tráfico cometidas a gran escala, y que puedan ser detectadas como consecuencia de un control de tráfico. En ese tipo de situaciones no sería razonable exigir a la autoridad competente que garantice todos los derechos protegidos por la presente Directiva. En caso de que la legislación de un Estado miembro prevea la imposición de una sanción para infracciones menores por parte de una autoridad de ese tipo, y la sanción pueda ser objeto de recurso ante un tribunal con competencia en materia penal, la presente Directiva solo debe aplicarse a los procesos ante dicho tribunal a raíz del recurso en cuestión». Art. 1.3 Directiva 2010/64/UE.

40 Véase infra el estudio de la jurisprudencia del TJ, dentro del epígrafe dedicado al análisis del significado y límites de la expresión «documentos esenciales».

41 Art. 62 LO 4/2000 sobre derechos y libertades de los extranjeros en España y su integración social. 
o denegando su ingreso en el Centro de Internamiento de Extranjeros (CIE). Este procedimiento no es proceso penal desde el punto de vista de la directiva, pues no se le imputa ningún hecho punible, sin embargo, desde el punto de vista del derecho interno la persona detenida goza de todos los derechos recogidos en el art. 520.2 LECrim, entre los que está el derecho a intérprete y a traducción ${ }^{42}$.

Por lo que respecta al límite desde el punto de vista de la extensión o desarrollo del procedimiento, la sentencia dictada por el TJ el 9 de junio de 2016 en el asunto Balogh ${ }^{43}$ establece claramente la frontera en la resolución definitiva sobre la responsabilidad penal del acusado. De modo que todo procedimiento posterior a esta resolución queda fuera del ámbito de la directiva, es decir, que el derecho a intérprete y a traducción de documentos esenciales en los procesos penales no se extiende más allá de la sentencia que declara que el acusado ha cometido, o no ha cometido, los delitos por los que ha sido encausado. En este asunto el TJ respondió a una petición de decisión prejudicial presentada por el Tribunal General del Extrarradio de Budapest en el marco de un procedimiento relativo al reconocimiento en Hungría de los efectos de una sentencia firme dictada por un órgano jurisdiccional de otro Estado miembro (Austria) por la que se condenó al Sr. Balogh a una pena de privación de libertad por la comisión de una infracción penal, así como a las costas del procedimiento ${ }^{44}$. En este caso se trataba de determinar si el derecho a la

42 La naturaleza administrativa de este procedimiento podría suscitar dudas sobre la aplicación de los derechos de la directiva al mismo, pero resuelve esta duda López Jara (2015) acudiendo al Tribunal Constitucional, cuya jurisprudencia ha señalado que la decisión ordenando o denegando el internamiento es una decisión judicial, con independencia del carácter administrativo de la expulsión (sentencia del Tribunal Constitucional de 7 de julio de 1987, 115/1987).

43 Sentencia del Tribunal de Justicia de 9 de junio de 2016, Balogh, C-25/15, EU:C: 2016:423.

44 Los hechos, narrados por el abogado general Yves Bot en sus conclusiones generales presentadas el 20 de enero de 2016 (EU:C:2016:29), fueron los siguientes: mediante sentencia de 13 de mayo de 2014, el Tribunal Regional de Eisenstadt (Austria) impuso al Sr. Balogh, húngaro, una pena privativa de libertad de cuatro años y seis meses por un robo con fuerza, condenándole asimismo al pago de las costas procesales. El 15 de septiembre de 2014 el Tribunal Regional de Eisenstadt transmitió los principales datos de la sentencia al registro austriaco de antecedentes penales mencionando el código previsto en el Sistema Europeo de Información de Antecedentes Penales (ECRIS) correspondiente a los delitos que dieron lugar a la condena. El 21 de septiembre de 2014 el registro austriaco de antecedentes penales informó a la autoridad central húngara de la sentencia, por vía electrónica, como se prevé en el marco del 
traducción consagrado en la Directiva 2010/64 era aplicable al procedimiento especial de reconocimiento de una sentencia dictada en otro Estado miembro, en definitiva, la cuestión jurídica que se planteaba era la de interpretar el concepto de "proceso penal» a efectos de la Directiva ${ }^{45}$.

El planteamiento de esta cuestión tuvo el efecto colateral de poner de manifiesto la existencia de una regulación húngara contraria al art. 82.1, párr. $1^{\circ}$ del Tratado de Funcionamiento de la Unión Europea (TFUE), que impone el reconocimiento mutuo de las sentencias y resoluciones judiciales como base de la cooperación judicial penal en la UE ${ }^{46}$. Aunque el TJ ha de limitarse a

ECRIS. A continuación el Ministerio de Justicia húngaro señaló al Tribunal Regional de Eisenstadt que era necesario que le comunicara la sentencia a los efectos de que su eficacia fuera reconocida en Hungría como si hubiese sido dictada por un tribunal húngaro, lo que se tramita a través del «procedimiento especial de reconocimiento de resoluciones extranjeras» establecido en el derecho húngaro ante el órgano competente, que es el Tribunal General del Extrarradio de Budapest, y consiste en la traducción de la resolución al húngaro. Este órgano se pregunta si los costes de este procedimiento pueden o no ser imputados al Sr. Balogh, dado que fue condenado a las costas, y en derecho húngaro los costes de traducción se consideran costas procesales penales. En Hungría el pago de las costas de traducción incumben al Estado en virtud de lo establecido en el art. 1.1. Directiva 2010/64 y de acuerdo con la Ley húngara de enjuiciamiento criminal, que reconoce al inculpado nacional húngaro el derecho a usar su lengua materna. Pero la necesaria traducción de una sentencia al húngaro a efectos de su reconocimiento no guarda ninguna relación con el derecho a utilizar la lengua materna. Por tanto el condenado, habiendo sido condenado en costas, tiene que pagar los costes del procedimiento especial de traducción en que consiste el reconocimiento. Las cuestiones elevadas al TJ fueron: «¿Debe entenderse el art. 1.1. de la Directiva 2010/64 en el sentido de que los tribunales húngaros deben aplicar esta Directiva también al procedimiento especial previsto en el derecho húngaro, y por lo tanto debe entenderse este procedimiento especial comprendido en la expresión "procesos penales"? ¿O Solamente son "procesos penales" a efectos de la aplicación de la Directa los que concluyen con una resolución definitiva sobre la responsabilidad del inculpado?». Recibida la cuestión, el TJ solicitó del Tribunal General del Extrarradio de Budapest saber si la sentencia dictada por el tribunal austriaco había sido traducida al húngaro en Austria y notificada así a la persona condenada. El Gobierno austriaco manifestó que había estado asistido por un intérprete húngaro durante la vista y había traducido oralmente la sentencia al condenado, y posteriormente por escrito. En consecuencia el TJ consideró que el Sr. Balogh había disfrutado de la traducción de la sentencia dictada contra él, es decir del derecho establecido en el art. 3 de la directiva. El Gobierno húngaro precisó que la traducción solicitada es necesaria para «ajustar formalmente la sanción establecida en la sentencia extranjera al húngaro y adecuarla a la ley húngara». Esta respuesta fue reveladora de la existencia de un procedimiento especial que se 
responder a las cuestiones que le son planteadas, en este caso la relativa a la interpretación de la Directiva 2010/64, lo cierto es que esta deriva del incumplimiento de las decisiones marco (DM) que establecen el sistema ECRIS, por lo que el Tribunal consideró que no podía obviarlo y, en consecuencia, reformuló la cuestión planteada del siguiente $\operatorname{modo}^{47}$ :

[...] ha de entenderse que la cuestión prejudicial planteada tiene por objeto que se dilucide, en esencia, si la Directiva 2010/64 y las DM 2009/315 y 316 deben interpretarse en el sentido de que se oponen a la aplicación de una normativa nacional que establece un procedimiento especial de reconocimiento por el juez de un Estado miembro de una resolución definitiva dictada por un tribunal de otro Estado miembro por la que se condena a una persona por la comisión de una infracción penal, como el procedimiento especial controvertido en el litigio principal, que prevé que los costes de traducción de esa resolución debe sufragarlos esa persona.

Responde el TJ que los gastos del procedimiento de reconocimiento no entran en el ámbito de la directiva, dado que el art. 1.2 de la directiva establece que se aplica hasta la conclusión del proceso (entendido como la resolución definitiva de la cuestión de si el sospechoso o acusado ha cometido o no la infracción penal, incluida la sentencia y en su caso la resolución de cualquier recurso que se haya presentado) y el procedimiento especial para el reconocimiento de una resolución definitiva tiene lugar por definición después de la resolución definitiva de la cuestión de si el sospechoso o acusado ha cometido o no la infracción penal, por lo tanto el Sr. Balogh no tiene derecho a su

asemeja demasiado a un exequatur, utilizado de manera sistemática para dar validez y eficacia a las resoluciones extranjeras, con claro incumplimiento del sistema ECRIS. A partir de ese momento se constató la existencia de dos problemas distintos: 1) la interpretación de la expresión «procesos penales» de la Directiva 2010/64 sobre derecho a traducción y a intérprete en los procesos penales, y 2) el incumplimiento por la República de Hungría de las DM de 2009 (315 y 316, ambas DO L 93 de 7 de abril de 2009) por las que se estableció el ECRIS.

47 Para poder inmiscuirse en el segundo problema detectado que no había sido sometido a su consideración, recurrió a una técnica que utiliza discrecionalmente, que es la de afirmar la necesidad de hacerlo para poder dar una «respuesta útil» al órgano remitente: «Con carácter preliminar, ha de recordarse que, según jurisprudencia reiterada del TJ, éste puede, para proporcionar una respuesta útil al órgano jurisdiccional que le ha planteado una cuestión prejudicial, verse obligado a tomar en consideración normas de Derecho de la Unión a las que el juez nacional no se haya referido en el enunciado de su cuestión. Además corresponde, en este caso, al TJ reformular las cuestiones que se le han planteado» (apdo. 28 de la sentencia, y apoya su actuación con cita de jurisprudencia anterior). 
traducción gratuita. Sin embargo, también declara que no procede la traducción de las sentencias en el marco ECRIS en ningún caso $^{48}$, por lo que no puede imponerse el coste de tal traducción al condenado. Tales gastos no son necesarios, y dado que es una exigencia del Estado húngaro habrá de pagarlos el Estado húngaro. Es más, si se realiza el procedimiento que los causa, el Estado húngaro está incumpliendo el derecho de la UE. Con este fallo el TJ estaba emplazando a la Comisión a actuar en su papel de guardiana de los tratados, ya que con esta información en su poder la Comisión está obligada a poner en marcha un procedimiento de infracción que puede desembocar en un recurso por incumplimiento del derecho de la Unión contra la República de Hungría.

\section{DERECHO A INTÉRPRETE: CONSECUENCIAS DE SU ÍNTIMA VINCULACIÓN CON EL DERECHO FUNDAMENTAL DE DEFENSA}

En un proceso como el penal en el que predomina la oralidad, la actividad de los intérpretes es fundamental. Y en el procedimiento de ejecución de una OED su intervención es condición de validez de toda decisión expresada por la persona detenida, cuando esta no entiende la lengua del Estado de ejecución de la orden ${ }^{49}$. El derecho al intérprete está íntimamente vinculado al derecho de defensa, y de su íntima vinculación se derivan al menos las cinco siguientes consecuencias:

a) Ha de ser entendido como un derecho absoluto en el sentido de ser exigible durante todas las sesiones del interrogatorio policial, las reuniones entre el sospechoso y su abogado directamente relacionadas con la preparación de su defensa y, tras las formulación de los cargos, las comparecencias ante el tribunal, así como para todas las comunicaciones personales, y en general siempre y en cualquier situación en que la

48 Sobre las DM que establecen el sistema ECRIS el TJ recuerda que el sistema creado recurre a un formato europeo normalizado que permite transmitir toda la información sobre condenas penales de manera homogénea, informatizada, comprensible y fácilmente traducible por medio de mecanismos automatizados, con ayuda de formularios uniformes y códigos. Y que ambas normas se oponen a un procedimiento especial de reconocimiento.

49 Es singularmente trascendental en decisiones tan fundamentales como su consentimiento o no a la entrega, y la renuncia o no al principio de especialidad. Nuestra regulación prevé una audiencia ante el juez central de instrucción con esta finalidad (art. 51 de la Ley 23/2014 de reconocimiento mutuo). Sobre todo el procedimiento y dificultades prácticas que plantea, véase Ruz Gutiérrez, 2017: 100 y ss. 
persona no comprenda la lengua del procedimiento (Jimeno Bulnes, 2007: 157$)^{50}$. El derecho al intérprete para las comunicaciones entre el abogado y el cliente no está expresamente reconocido en algunos Estados miembros ${ }^{51}$, por lo que este nivel mínimo común va a suponer un avance en las garantías procesales en tales casos.

Asimismo se afirma que tiene carácter absoluto porque puede ser considerado manifestación del derecho a estar presente en el juicio, dentro del principio de que nadie puede ser condenado sin ser oído, incluido en el derecho a la última palabra, que no podrá ejercitar si no comprende el idioma en que se desarrollan las actuaciones (López Jara, 2015: 8).

b) En derecho español es un derecho irrenunciable, como lo proclama el art. 126 LECrim en relación con el art. 123.1.a) y c) LECrim ${ }^{52}$.

c) Corresponde al juez verificar la necesidad de interpretación, de conformidad con lo establecido en el considerando 21 de la directiva ${ }^{53}$, que incorpora por esta vía jurisprudencia del $\mathrm{TEDH}^{54}$. Esta previsión

50 Este es el sentido dado a este precepto en la explicación que acompaña a la exposición de motivos de la LO 5/2015 por la que se implementa la Directiva 2010/64, donde se aclara que debe ofrecerse durante las fases de investigación y judicial del proceso, incluida la apelación, y que se amplía al asesoramiento jurídico que ha de facilitarse al sospechoso cuando su abogado hable una lengua que él desconoce. Y lo mismo se deduce también de la lectura de los considerandos 17, 18 y 19 de la Directiva 2010/64.

51 Así en República Checa, Lituania o Portugal. Véase el informe TRAINAC: Proyecto sobre garantías procesales del CCBE (Consejo de los Colegios de Abogados de la Comunidad Europea - Consejo de la Abogacía Europea) y la ELF (European Lawyers Federation), pp. 12 y ss.

52 Ambos modificados por la LO 5/2015.

53 «Los Estados miembros deben velar porque se establezca un procedimiento o mecanismo para determinar si el sospechoso o acusado habla y entiende la lengua del proceso penal y si se requiere la asistencia de un intérprete. Este procedimiento implica la comprobación adecuada por parte de la autoridad competente, incluso consultando al sospechoso o acusado, de si la persona en cuestión habla y entiende la lengua del proceso penal y si requiere la asistencia de un intérprete».

54 Sentencia TEDH de 14 de octubre de 2014, Baytar c. Turquía, CE:ECHR:2014:1014JUD004544004. La Sra. Baytar se presentó en la prisión donde estaba interno su hermano por su vinculación con el PKK (Partido de los trabajadores del Kurdistán, considerado una organización terrorista) y fue detenida al descubrir que llevaba una carta sin firmar redactada por un miembro del PKK y dirigida a otro miembro. Fue interrogada el mismo día en turco ante los gendarmes, el fiscal y el juez, y al ser analfabeta firmó el acta con su huella dactilar. Tras un breve período en prisión preventiva fue puesta en libertad. En una nueva visita se encontró en su vestido un documento de dieciséis páginas. De nuevo fue interrogada en lengua turca por los gendarmes 
constituye un avance en el sistema común de garantías procesales, porque la mayoría de los Estados miembros carecen de un método para evaluar esta necesidad (saber si es el órgano competente, determinar el nivel mínimo de conocimiento del idioma para entender por completo el proceso penal... $)^{55}$. Tiene que ser así porque la vulneración de este derecho tiene consecuencias sobre la validez del proceso ${ }^{56}$, dada la importancia de la fase de investigación para la preparación del proceso. Las pruebas obtenidas durante esta fase pueden ser determinantes para el curso del proceso $^{57}$, y la ausencia de control inicial sobre la necesidad de intérprete tiene repercusiones sobre otros derechos estrechamente vinculados, de modo que compromete la equidad del proceso en su conjunto ${ }^{58}$. No puede ser, pues, considerada como correcta la decisión de una persona acusada de renunciar, o no, al derecho a guardar silencio o a un abogado cuando no es capaz de medir las consecuencias de la misma por no comprender claramente lo que está decidiendo ${ }^{59}$.

d) No hay vulneración del derecho a intérprete cuando su ausencia no ocasiona indefensión alguna. Nuestro Tribunal Supremo ha interpretado que en supuestos en que la actuación consiste en el cumplimiento de un registro ordenado judicialmente sin que se tome declaración al así detenido, no hay vulneración del derecho a intérprete. Partiendo de la consideración de la íntima vinculación de este derecho con el de defensa, el TS ha declarado que cuando la ausencia de intérprete no ocasiona indefensión alguna, porque la vulneración se alega en relación con una prueba objetiva, por tanto de recogida de efectos y no de declaraciones, estamos ante una alegación meramente formal que como tal no puede

y de nuevo firmó con la huella dactilar el acta en la que se indicaba que se le había recordado su derecho a la asistencia de un abogado pero que no había expresado su deseo de utilizarlo. En el juicio que siguió a esta segunda detención el juez solicitó a un miembro de la familia de la Sra. Baytar que hiciera de intérprete, al constatar que ella no hablaba suficientemente bien el turco. Cuando tuvo conocimiento, durante las vistas celebradas ante este juez, del contenido de las actas que había firmado con su huella dactilar, atacó su veracidad.

Para un conocimiento detallado de la situación a nivel interno en cada Estado miembro véase el informe de la FRA (2016: 31 y ss.).

56 Sentencia TEDH, Baytar c. Turquía, cit., apdo. 53.

57 Ibid., apdo. 53.

58 Ibid., apdo. 55.

59 Ibid., apdo. 54. 
$\operatorname{prosperar}^{60}$. Por tanto y dado que el derecho de defensa se exterioriza por medio del letrado, cabe concluir que toda actuación que se lleve a cabo con un sospechoso en la que sea necesaria la presencia de letrado requiere la asistencia de intérprete si no conoce la lengua del procedimiento, ya que es este el que hace posible que pueda recibir asesoramiento sobre el contenido y el alcance de tal actuación así como las consecuencias procesales que se derivan (López Jara, 2015: 7) ${ }^{61}$, y viceversa: cuando la ausencia de letrado no causa indefensión tampoco la causa la ausencia de intérprete.

e) El intérprete de la defensa está dispensado de la obligación de declarar sobre los hechos traducidos en las conversaciones y comunicaciones entre el investigado o acusado y su letrado ${ }^{62}$, como consecuencia de la confidencialidad que le exige el art. 124.2 LECrim. Esta confidencialidad es un extremo esencial para la efectiva defensa del inculpado, por lo que resulta un aspecto muy delicado que ha de gozar de salvaguardias suficientes. En la práctica encontramos, sin embargo, que es habitual que se utilicen los mismos intérpretes para actuar en las comunicaciones entre

60 Sentencia del Tribunal Supremo de 26 de junio de 2012, 535/2012. El ponente, C. Conde-Pumpido, acudió a la regulación comunitaria como canon de interpretación de la exigencia del derecho al intérprete, aunque no era preceptivo porque todavía no se había implementado al ordenamiento español. El supuesto consistió en la detención de varias personas de habla inglesa en altamar en un registro autorizado judicialmente de una embarcación que transportaba más de tres toneladas de hachís, durante el tiempo necesario para su traslado al puerto de Ibiza. En tierra se practicó el registro sin la presencia de intérprete. Alegada esta ausencia como constitutiva de nulidad de todo lo actuado, el TS no la estimó, ya que entendió que tratándose de una diligencia que ordinariamente se lleva a cabo con urgencia en presencia de los interesados pero contra su voluntad, y en la que no es necesaria presencia de letrado porque no se toma declaración aunque siempre bajo control jurisdiccional asegurado por la asistencia del secretario (ahora letrado de la Administración de Justicia), y cuyo objeto es la recogida de efectos y no las manifestaciones de los acusados, "no es suficiente con constatar que un inculpado es extranjero y precisa de intérprete en la práctica de una diligencia de entrada y registro para reputar vulnerado el derecho constitucional de defensa, es preciso que la ausencia de intérprete haya ocasionado una real y efectiva indefensión». En su trabajo el autor extracta de la jurisprudencia del TS las siguientes actuaciones: entrada y registro en domicilio con consentimiento del titular detenido o acordada cuando ya tiene designado letrado, la participación en una rueda de reconocimiento, formación de cuerpo de escritura, reconstrucción de hechos, toma de muestras del sospechoso detenido con su consentimiento para la práctica de una prueba de ADN. Nuevo art. $416.3^{\circ}$ LECrim. 
el letrado y su cliente, y entre este y los funcionarios de policía y/o del juzgado. Esto sucede especialmente en los sistemas donde los intérpretes son designados oficialmente por el órgano competente ${ }^{63}$.

Con esta dispensa se evitan por una parte los riesgos de parcialidad que inevitablemente lleva consigo su actuación, y por otra, los riesgos que su intervención puede tener para su integridad o la de su familia.

\section{DERECHO A LA TRADUCCIÓN DE DOCUMENTOS ESENCIALES}

\section{SIGNIFICADO Y LÍMITES DE LA EXPRESIÓN «DOCUMENTOS ESENCIALES»}

Es evidente que un Estado miembro no puede enjuiciar a una persona que no entiende la lengua de procedimiento sobre la base de documentos esenciales que deberían haberle sido traducidos pero no lo han sido ${ }^{64}$. Ahora bien, no todos los documentos que se producen en el curso de un proceso penal necesitan ser traducidos, sino únicamente los que tienen carácter de "esenciales» ${ }^{65}$. En el texto de la directiva se consideran tales como mínimo: la decisión por la que se priva a una persona de libertad (y añadimos los materiales que fundamentan esta decisión ${ }^{66}$ ), los escritos de acusación y las sentencias, así como la traducción de la orden europea de detención.

Fuera de los documentos expresamente mencionados, se deja en manos de las autoridades competentes la determinación del carácter esencial de un documento ${ }^{67}$. Para salvaguardar el derecho a traducción e intérprete frente a

63 Véase in extenso el informe TRAINAC del CCBE (2016: 11 y ss).

64 Palabras del AG Wahl en el punto 44 de sus conclusiones al asunto Sleutjes, (C278/16, EU:C:2017:366).

65 De nuevo la norma comunitaria incorpora la jurisprudencia del TEDH, singularmente de los casos Kamasinski y Hermi citados supra, donde declara que este derecho «no llega hasta el punto de exigir la traducción por escrito de todas las pruebas documentales y de todos los autos del procedimiento [...pero...] debe permitir al acusado conocer de que se le acusa y defenderse» (apdo. 74, párr. segundo, asunto Kamasinski).

66 Porque cuando se tiene derecho a acceder a los materiales del expediente de una persona detenida o privada de libertad en cualquier fase del proceso penal, hay que considerar que también se tiene derecho a su traducción (por necesidad, para hacer real el derecho del art.4.2 a de la Directiva 2012/13/UE sobre el derecho a información).

67 En España plantea problemas para los tribunales y las defensas la determinación de qué constituyen «documentos», y de entre los documentos a efectos de la directiva, cuales son «esenciales» (Campaner Muñoz, 2017). El autor revela cómo en la práctica 
un posible abuso de las autoridades, la resolución por la que deciden que no es necesaria una traducción (o la intervención de un intérprete) tiene que poder ser objeto de recurso, ya sea de modo independiente, ya sea al impugnar otra resolución judicial que se fundamente sobre actuaciones afectadas por la decisión negativa ${ }^{68}$. En España el nuevo art. 123.1.e) LECrim prevé que el encausado puede solicitar que se considere esencial un documento, así como el derecho a recurrir las decisiones dictadas que le perjudiquen ${ }^{69}$. Nuestro TS interpreta «documento esencial» para garantizar el derecho de defensa sin constreñirse a los presumidos como tales en la directiva, de modo paralelo a cómo interpreta los límites vistos del derecho a intérprete, y en consecuencia no considera vulnerado el derecho por la falta de traducción si la indefensión que se alega es meramente formal y no material, única causante de la efectiva privación de algún medio de defensa o su limitación ${ }^{70}$.

El TJ ha tenido ocasión de pronunciarse ya en dos ocasiones sobre el significado de «documentos esenciales» frente a la negativa de la autoridad nacional de reconocer como tal un documento distinto de los expresamente mencionados en la norma. Se trata de los asuntos Covaci y Sleutges. Ambos supuestos han surgido en relación con la llamada «resolución de autorización de decreto de propuesta de imposición de pena», de la legislación procesal penal alemana $^{71}$. El procedimiento para la adopción de una resolución judicial de

los tribunales han denegado la traducción de los informes policiales y del interrogatorio del sospechoso por no tener carácter de documentos, o de la denuncia, por quedar sucedida por el escrito de acusación que sí que ha sido traducido..., en definitiva, por una confusión de lo que son elementos probatorios con elementos importantes para desarrollar la defensa del acusado.

Art. 2.5 y art. 3.5 Directiva 2010/64/UE.

69 Art. 125.2 LECrim, incorporando los arts. 2.5 y 3.5 de la directiva.

70 El TS ha declarado que la falta de traducción de un documento esencial como es el escrito de acusación no vulnera este derecho cuando no se le causó indefensión material alguna. En tal situación «se podrá hablar de indefensión formal por el incumplimiento del deber de traducción que se impone en el art. 123.1 d LECrim [... sin embargo...] el incumplimiento al menos aparente de dicha obligación no le causó indefensión material alguna [...] atendiendo a la finalidad del precepto hemos de considerar que falta el presupuesto inicial, es decir, que el acusado no entienda el idioma castellano [...] De este modo [...] queda descartado que la falta de traducción del escrito de acusación hubiera causado indefensión. Es por ello que [...] resulta patente la inexistencia de indefensión material alguna» (sentencia TS de 29 de junio de 2017, ES:TS:2017:2653, fundamento de derecho primero).

71 Explica este procedimiento Ollé Sesé (2016). De acuerdo con este autor, el procedimiento más parecido contemplado en nuestra legislación es el denominado "proceso 
autorización de un decreto de propuesta de imposición de pena (arts. 407 y ss. $\mathrm{StPO}$ ) es un procedimiento sumario que no prevé la celebración de una vista ni un debate contradictorio, de modo que para la persona acusada la única posibilidad de acceder a un debate contradictorio es la de formular oposición contra la resolución (en un plazo de dos semanas, transcurridas las cuales deviene firme). Por otra parte, la legislación alemana establece que la lengua de procedimiento ante los tribunales alemanes es exclusivamente el alemán.

En el asunto Covaci $^{72}$ el TJ devuelve al órgano nacional la responsabilidad de definir «documento esencial». El Sr. Covaci, de nacionalidad rumana, fue detenido en un control rutinario de policía y se comprobó que conducía por territorio alemán sin póliza de seguro obligatorio de responsabilidad civil y con una carta verde falsa. Durante el interrogatorio ante la policía fue asistido por un intérprete. La Fiscalía solicitó al Tribunal que dictara una orden penal de imposición de una multa. Al no disponer de domicilio en Alemania el Sr. Covaci otorgó un poder a tres funcionarios del tribunal a efectos de la notificación de los documentos judiciales de los que fuera destinatario. El plazo de dos semanas para oponerse comienza a partir de la notificación de la resolución a estos representantes. La Fiscalía pidió expresamente que las observaciones que quisiera hacer el Sr. Covaci las redactara en alemán. El tribunal se planteó dudas sobre si esta normativa era compatible con la directiva y formuló al TJ la siguiente pregunta: ¿¿deben interpretarse los arts. 1.2, 2.1 y 2.8 en el sentido de que se oponen a una regulación en la que el juez imponga a los acusados como condición de admisibilidad de un recurso que esté redactado en lengua alemana?

El TJ aclaró en primer lugar que «la situación de una persona como el Sr. Covaci, que desea impugnar una orden penal que aún no ha adquirido firmeza y de la que es destinatario está incluida en el ámbito de aplicación de esta Directiva ${ }^{73}$, por lo que dicha persona ha de disfrutar de los derechos en ella contemplados. Pero la verdadera cuestión era saber si se puede invocar este derecho para formular la oposición contra tal orden en una lengua distinta de la del procedimiento ante el tribunal nacional, por lo que el TJ recondujo la cuestión a la interpretación del art. 2, y sobre todo del art. 3 de la directiva, en relación con el derecho a interpretación y a traducción de «documentos

por aceptación de decreto» introducido en la LECrim por la Ley 41/2015, arts. 803 bis a -803 bis $\mathrm{j}$.

72 Sentencia del Tribunal de Justicia de 15 de octubre de 2015, Gavril Covaci, C-216/14, EU:C:2015:686.

73 Sentencia del Tribunal de Justicia de 15 de octubre de 2015, Gavril Covaci, cit., apdo. 27. 
esenciales», y precisó: por lo que respecta al derecho a interpretación, el problema está en que este es de aplicación a declaraciones orales. La directiva establece que la obligación de ofrecer la asistencia de intérprete únicamente alcanza a situaciones que dan lugar a comunicaciones orales ${ }^{74}$. Es decir, «cuando esta persona haya de realizar por sí misma declaraciones orales en el marco de un proceso penal, ya sea directamente ante las autoridades judiciales competentes o destinadas a su abogado, (para que) pueda hacerlo en su propia lengua ${ }^{75}$. Por consiguiente, este derecho a la asistencia de intérprete "tiene por objeto la traducción de las comunicaciones orales [...] pero no la traducción escrita de todo documento escrito aportado por dicho acusado». De modo que el art. 2 de la directiva "garantiza [...] la asistencia gratuita de un intérprete si formula ella misma de modo oral una oposición contra la orden penal $[\ldots] »^{76}$. Mientras que el art. 3 de la directiva "confiere el derecho a asistencia en materia de traducción a una persona que se halle en una situación como la del Sr. Covaci que desee formular oposición por escrito contra una orden penal sin la asistencia de un abogado», "el derecho de traducción establecido en el art. 3 no incluye, en principio, la traducción escrita en la lengua de procedimiento de un documento, como la oposición formulada contra una orden penal, redactado por la persona afectada en un idioma que domina pero que no es la de procedimiento ${ }^{77}$. La directiva no es, pues, de aplicación a la situación del Sr. Covaci, pero el TJ recuerda que la directiva es una norma de mínimos, y deja abierta la puerta a una extensión de su aplicación en su apdo. 50: «Corresponde al órgano jurisdiccional remitente determinar si la oposición formulada por escrito contra una orden penal debe considerarse un documento esencial».

De acuerdo con la jurisprudencia Covaci, correspondía pues a los tribunales alemanes decidir si la resolución de autorización de decreto de propuesta de imposición de una multa era un documento esencial y en cuanto tal tenía que ser traducido.

En el segundo caso, el asunto Sleutjes ${ }^{78}$, el abogado general propuso al TJ que se pronunciase y que no derivase de nuevo la solución a las autoridades nacionales ${ }^{79}$. Al Sr. Sleutjes, neerlandés, se le imputó un delito de abandono indebido del lugar de un accidente, castigado con pena de multa. El Sr.

\footnotetext{
74 Ibid., apdo. 28.

75 Ibid., apdo. 33.

76 Ibid., apdo. 42.

77 Ibid., apdo. 47.

78 Sentencia del Tribunal de Justicia de 12 de octubre de 2017, Frank Sleutjes, C-278/16, EU:C:2017:757.

79 Conclusiones del AG Wahl, Frank Sleutjes, C-278/16, EU:C:2017:366.
} 
Sleutjes formuló su oposición mediante un correo electrónico redactado en neerlandés, solicitando asimismo un intérprete de lengua alemana. Al no estar redactados en alemán, los correos se tuvieron por no enviados válidamente y en consecuencia por no recibidos. El Sr. Sleutjes decidió entonces acudir a un abogado alemán para que formulase la oposición en el idioma del tribunal, que fue inadmitida por extemporánea al haber superado el plazo de dos semanas. En este momento el tribunal alemán se cuestionó la validez de la notificación inicial de la resolución de autorización al Sr. Sleutjes, realizada en alemán y sin acompañarla de una traducción al neerlandés. Se cuestionó si dicha notificación es un documento esencial que como tal debería haber sido traducido, dado que supone el dies a quo del plazo de dos semanas para formular la oposición.

En sus conclusiones el AG Wahl defendió que, sin lugar a dudas, la resolución judicial de autorización de decreto de proposición de imposición de pena es un documento esencial a efectos de la directiva ${ }^{80}$. Y basó esta afirmación sobre tres pilares: el tenor, el contexto y la finalidad de la directiva, es decir, que realizó una triple interpretación de la directiva: gramatical, sistemática y teleológica. Utilizando el método gramatical, o atendiendo al tenor del texto de la directiva en palabras del AG, acudió al art.3.1 para encontrar los documentos acogidos (que son los «documentos esenciales parar garantizar que esté en condiciones de ejercer el derecho de defensa y para salvaguardar la equidad del proceso») así como al art. 3.2, que especifica que entre los documentos esenciales están las sentencias. De ambos deriva que «una resolución adoptada por un órgano jurisdiccional que adquiere firmeza si no se impugna en el plazo previsto presenta algunas semejanzas con una "sentencia" ${ }^{1}[\ldots]$ por consiguiente deberá considerarse [...] como un documento esencial» ${ }^{82}$. En segundo lugar, siguiendo el método sistemático, es decir atendiendo al contexto, observó que el art. 1.3 de la norma excluye algunas sanciones administrativas por ser infracciones menores. El considerando (16) de la misma aclara que el objeto de esta exclusión es eliminar la obligación que supondría para las autoridades administrativas en casos en los que no sería razonable su aplicación, y simultáneamente sirve para confirmar que una resolución judicial

80 Conclusiones, Frank Sleutjes, C-278/16, EU:C:2017:366, punto 27.

$81 \mathrm{Y}$ con un escrito de acusación porque, por una parte, esta resolución solo se produce después de que el juez se haya pronunciado sobre la procedencia de la acusación, y por otro lado es la primera ocasión en que se informa de la acusación a la persona afectada. Y transcurrido el plazo para oponerse esta resolución adquiere firmeza y las sanciones que impone son ejecutables.

82 Punto 30, conclusiones, Frank Sleutjes, C-278/16, EU:C:2017:366. 
que pueda conllevar la imposición de una sanción por una infracción de tráfico por un hecho que no sea simple exceso de velocidad es un supuesto típico en el que son aplicables los derechos consagrados en la directiva. En tercer y último lugar, desde un punto de vista teleológico, o atendiendo a la finalidad de la norma, el AG considera que esta consiste, según refiere el considerando (14), en garantizar el derecho a un juicio justo, de conformidad con el derecho consagrado en el art. $6 \mathrm{CEDH}$, cuya aplicación práctica afirma facilitar la directiva. De tal modo que no exigir la traducción de una resolución judicial que puede dar potencialmente lugar a la imposición de una sanción firme, en realidad supondría una denegación de justicia ${ }^{83}$. Y finalmente argumenta que cuando el art. 3.3 dice que corresponde a las autoridades competentes decidir si resulta esencial otro documento, se refiere a documentos distintos de los que ya se consideran esenciales en el art. 3.1 y $3.2^{84}$. Acogiendo el razonamiento de su AG, el TJ declaró que

un acto como una resolución prevista por el Derecho nacional para sancionar infracciones penales leves dictada por un juez tras un procedimiento unilateral abreviado constituye un "documento esencial" [...] del cual deben recibir una traducción escrita que respete los requisitos formales que establece la referida disposición, las personas sospechosas o acusadas que no comprendan la lengua del proceso de que se trate, con el fin de permitirles ejercer su derecho de defensa y de salvaguardar de este modo la equidad del proceso ${ }^{85}$.

"Una resolución judicial de esta naturaleza constituye, al mismo tiempo, un escrito de acusación y una sentencia, en el sentido del art. 3.2 de la Directiva $2010 / 64\rangle^{86}$.

\section{ALCANCE DEL DERECHO A TRADUCCIÓN GRATUITA}

El derecho a la traducción de documentos esenciales lo es de la lengua del procedimiento a la que la persona comprenda, de modo que le permita tener conocimiento de los cargos que se le imputan, pero no exclusiva ni necesariamente a la lengua materna ${ }^{87}$.

83 Ibid., punto 34 .

84 Ibid., punto 35, donde el AG asemeja esta decisión a una sentencia.

85 Sentencia del Tribunal de Justicia de 12 de octubre de 2017, Frank Sleutjes, C-278/16, EU:C:2017:757, apdo. 34.

86 Ibid., apdo. 31.

87 Conclusiones del AG Wahl, Frank Sleutjes, cit., punto 40. 
Ha de considerarse como una vulneración de este derecho a la traducción de documentos esenciales el uso abusivo de la facultad de reducir los párrafos a traducir recogida en el art. 3.4 de la directiva, que permite al tribunal decidir no traducir aquellos pasajes de documentos esenciales que no resulten pertinentes para que el sospechoso o acusado tenga conocimiento de los cargos que se le imputan. Esta facultad ha de ser entendida dentro de sus límites, que no permiten que se sustituya la traducción de un documento esencial por información complementaria sobre las vías de recurso ${ }^{88}$.

Este derecho incide necesariamente en el cómputo de los plazos procesales, pues debe entenderse que estos no empiezan a correr desde la notificación del acto si este no va acompañado de una traducción en una lengua que el destinatario comprenda. Es así también en virtud del principio de equivalencia que rige en toda la regulación comunitaria, porque «las personas sospechosas o acusadas de haber cometido una infracción penal que no entiendan la lengua del procedimiento, no pueden tener un trato menos favorable que las personas que sí que comprenden esa lengua» ${ }^{89}$. Y por tanto los plazos no pueden empezar a correr hasta que dicha persona reciba una traducción adecuada de la resolución. La directiva no fija plazos dentro de los cuales ha de realizarse la traducción ${ }^{90}$, sino que acoge expresiones vagas como «sin demora» ${ }^{91} \mathrm{o}$ "en un plazo razonable» ${ }^{92}$; tampoco los ordenamientos nacionales, que aluden a «tan pronto como sea posible», «a la mayor brevedad»... Esta laguna es intensamente acusada en la práctica ${ }^{93}$, como han destacado los informes elaborados sobre la aplicación de la directiva, y se ha propuesto adoptar una horquilla de

88 Precisión que manifiesta el AG Wahl a lo largo de sus conclusiones, Frank Sleutjes, cit.

Conclusiones del AG Wahl, Frank Sleutjes, cit., punto 46.

$90 \mathrm{Ni}$ para los procesos penales ni para las OED, si bien en estas últimas la carencia ha sido resuelta por la Comisión en la última actualización del Manual europeo para la emisión y ejecución de órdenes de detención europeas, DOUE C335 de 6 de octubre de 2017, fijando una horquilla entre seis y diez días naturales para la traducción de la orden en el Estado de ejecución.

91 Art. 2.1.

92 Art. 3.1. Directiva 2010/64/UE, incorporado en el nuevo art. 123.4 LECrim.

93 Los tribunales españoles han reaccionado de modos muy diversos, incluida la posibilidad de ordenar el sobreseimiento de la causa hasta que se entregue la traducción solicitada. Esta solución violenta el instituto del sobreseimiento pues no se contempla «la traducción de un documento» como causa legal; ahora bien, está claro que no perjudica al encausado (véase más ampliamente Campaner Muñoz, 2017). 
entre tres y catorce días laborables ${ }^{94}$, y entre seis y diez días para la traducción del mandamiento de las $\mathrm{OEDyE}^{95}$.

Al contrario que el derecho al intérprete, el derecho a la traducción de documentos no es un derecho absoluto y por ello es posible renunciar al mismo $^{96}$. Pero, como toda renuncia de un derecho, para que sea válida tiene que respetar una serie de requisitos: ser voluntaria, inequívoca, y realizada con unas garantías mínimas (con asesoramiento previo y con pleno conocimiento de las consecuencias de su renuncia ${ }^{97}$.

\section{CONSIDERACIONES FINALES}

1) Ya he expresado en trabajos anteriores mi valoración positiva de lo que ha supuesto la directiva ${ }^{98}$, partiendo del íntimo vínculo entre el derecho a intérprete y a traducción en un proceso penal con el derecho fundamental de defensa, pues sin un conocimiento real de lo que está ocurriendo es imposible desarrollar eficazmente ninguna defensa. $\mathrm{Y}$ ya puse

94 Siguiendo la práctica de la regulación escocesa. Tanto el informe de la FRA (2016) como el del CCBE (TRAINAC, 2016), citados supra, hacen un recorrido de las legislaciones nacionales para comprobar que se trata de un extremo carente también de regulación nacional. Sin embargo, también se ha constatado que algunos Estados miembros han desarrollado prácticas o elaborado directrices para concretar las vagas expresiones de la norma comunitaria.

De este modo se aclara este punto en la última actualización del Manual europeo para la emisión y ejecución de órdenes de detención europeas de la Comisión Europea, op. cit., p. 24, donde se recomienda «encarecidamente» este plazo, a la luz de la experiencia que ha demostrado que un plazo inferior repercute en la calidad de la traducción y un plazo superior puede hacer pensar en un excesivo retraso y por lo tanto en dilaciones indebidas.

96 Art. 3.7 Directiva 2010/64/UE. Así se acoge en nuestra legislación, en el nuevo art. 126 LECrim, que tiene rango de "orgánico» al afectar a la renuncia de derechos fundamentales, como se especifica en la disposición final segunda de la LO 5/2015 de reforma de la LECrim.

97 Campaner Muñoz (2017) pone de manifiesto que la práctica de los tribunales españoles no responde a estas exigencias, en unas ocasiones por el temor a incurrir en excesivas dilaciones que pudieran calificarse de indebidas, en otras por cesiones de los letrados para no perjudicar la defensa del acusado, o por no saber cómo gestionar la fase de instrucción mientras se está realizando la traducción solicitada y acordada.

Singularmente en Vidal Fernández (2010). Y con especial dedicación al estudio de la calidad y precisión de la traducción y la interpretación: Vidal Fernández (2007). 
asimismo de manifiesto lo que, consideré, suponían graves carencias de las que adolecía, en su momento agrupadas en tres apartados: insuficiencia de mecanismos vinculantes para garantizar la calidad y la integridad de lo interpretado y lo traducido; inexistencia de una obligación expresa de los Estados miembros de formar al personal llamado a intervenir en un proceso penal en su colaboración con el intérprete-traductor (el texto de la directiva se limita a decir que "se esforzarán»); y falta de protección de estos profesionales frente a los riesgos que puede correr su vida o su integridad física, o de parcialidad y de corrupción ${ }^{99}$. En el presente trabajo he centrado mis críticas en los límites de ambos derechos en su confrontación con la realidad, y una vez implementada la directiva mediante las exigidas reformas de nuestra legislación procesal.

2) Es fundamental un sistema unificado de acreditación a efectos de validar la calidad de los profesionales ${ }^{100}$. A las dificultades para diseñar tal sistema unificado se añaden los enormes costos que supondría su aplicación y el problema particular de las lenguas hasta ahora minoritarias ${ }^{101}$. Si se plantease la posibilidad de un reconocimiento de traductores e intérpretes judiciales incluidos en registros de otros Estados miembros, debería

99 Para cuyo conocimiento in extenso me remito nuevamente al trabajo citado en la nota anterior.

100 El libro verde de 2003 sobre garantías procesales resumía en tres los requisitos mínimos de los intérpretes y traductores judiciales para poder desempeñar esta labor: formación (en los siguientes extremos: traducción, interpretación, idiomas y también en los sistemas judiciales propios de los idiomas trabajados); acreditación (mediante un sistema de titulación y acreditación que exigiera su renovación periódica para asegurar la incesante actualización del profesional); y registro (de todos los profesionales acreditados, de fácil acceso para los juzgados y demás actores forenses). Esta medida, así como el establecimiento de un sistema de aranceles o de precios mínimos, eran también propuestas de estos profesionales de cara a garantizar un mínimo estándar de calidad en todo el territorio de la Unión Europea. Blasco y Del Pozo (2015: 9-40) presentan una propuesta para la acreditación de intérpretes judiciales en España, basada en los resultados del proyecto «Qualitas», en el que catorce expertos de siete países europeos diseñaron un sistema a partir de experiencias de éxito contrastado. En su propuesta, junto a los imprescindibles conocimientos previos (de técnicas, de idiomas, de sistemas legales y de normas deontológicas) añaden que el instrumento de evaluación de la acreditación se realice según parámetros preestablecidos, garantizando la fiabilidad de los evaluadores, y contando con la organización administrativa necesaria.

101 Conviene utilizar este calificativo con precaución, porque una lengua hablada por un porcentaje ínfimo de población mundial puede, sin embargo, constituir un porcentaje importante de población criminal en un determinado momento y lugar. 
garantizarse la reciprocidad, es decir, que los acreditados en España también sean reconocidos en los demás Estados (Blasco y Del Pozo, 2015: 22). Por lo que respecta a las llamadas lenguas minoritarias, puede resultar excesivo establecer un aparato oficial de acreditación con todas las exigencias formales fijadas para las lenguas de uso habitual, por ello resulta muy interesante la solución austríaca que acoge dos vías de acreditación: acceso mediante titulación y acceso por experiencia, sometidas a distintos requisitos incluidos plazos temporales diferentes ${ }^{102}$.

3) No cabe duda de que de todas las garantías procesales mínimas comunes, esta puede ser la más cara. Es indudable que es imposible contar con intérpretes de todas las lenguas en todos los tribunales para un eventual supuesto de un extranjero de esa lengua minoritaria. Consideramos que un camino inteligente y eficaz es el del uso de las nuevas tecnologías, que permitirán hacer real el derecho a intérprete de modo asumible desde un punto de vista económico. Generalizar la propuesta de la Asociación Europea de Intérpretes y Traductores Judiciales (EULITA: European Legal Interpreters and Translation Association) recogida en el informe TRAINAC de crear un hub o un pull de donde sacar los intérpretes que actúen por videoconferencia en cualquier juzgado de cualquier Estado miembro sería el medio ideal para hacer realidad este derecho absolutamente fundamental ${ }^{103}$. Para ello, obviamente, hay que crear la plataforma y el programa informáticos y por tanto crear el instrumento tecnológico que lo haga factible. Una posible solución es la de promover una aplicación/base de datos/registro de intérpretes compartidos a nivel de la UE, creando puntos de emisión dotados de la tecnología necesaria para hacer efectivas las garantías procesales de todo encausado en un proceso penal en la UE. Las nuevas tecnologías tienen que servir para facilitar la utilización conjunta de instrumentos y mecanismos consiguiendo la máxima eficiencia de los recursos disponibles, y el éxito constatado de las diferentes redes integradas por puntos de contacto fijados en los territorios de los Estados miembros nos muestra el camino, que en este caso ha de transitarse virtualmente. También es interesante la idea de Rojo Chacón (2015: 103) del intérprete "de guardia» como un apartado del registro, para todos los idiomas, en tribunales y en comisarías, si bien y para hacerlo posible nosotros lo especificaríamos como «guardia localizada».

102 Véase más ampliamente Rojo Chacón (2015: 104-105).

103 Trata detenidamente el uso de la videoconferencia Fernández Carrón (2017: 155195). 
4) Resultan muy peligrosas las facultades que la ley reconoce en el art. 123.3 LECrim al «funcionario competente» para decidir que párrafos no son esenciales y cuya traducción puede por tanto omitirse, y sobre todo la facultad de sustituir esta traducción ya amputada por un resumen oral. Advierte Guerrero Palomares (2016: 7) que este riesgo se incrementa porque el fundamento en el que se apoyan no reconoce como límite el derecho de defensa del imputado, sino que el imputado o acusado pueda conocer los hechos que se le imputan, es decir que se fundamentan en el derecho a la información, que es menos intenso que el de defensa. La segunda de las facultades señaladas, de sustituir la traducción por un resumen oral, queda limitada a «solo cuando de este modo también se garantice suficientemente la defensa del imputado o acusado». De nuevo el problema se plantea con la especificación del adverbio «suficientemente», que se deja a juicio del tribunal.

Ambas facultades resultan especialmente atractivas para los tribunales, tanto desde un punto de vista económico, por el ahorro que suponen para la Administración de Justicia, como desde un punto de vista procesal, pues ante el riesgo de paralización de la causa y a fin de evitar dilaciones que puedan ser calificadas de «indebidas», los jueces y los fiscales tenderán a acogerse a la posibilidad de sustituir «excepcionalmente» la traducción escrita por un resumen oral, con el previsible peligro de acabar convirtiendo en común lo que estaba previsto como situación excepcional.

5) El objetivo de la directiva es lograr normas mínimas comunes, sin perjuicio de la libertad de los Estados miembros para fijar normas más exigentes. La única condición que tales normas deberán cumplir siempre es el respeto de estos derechos tal como son consagrados por el CEDH y desarrollados por la jurisprudencia del TEDH ${ }^{104}$. La expresión «normas mínimas comunes», tan utilizada en el ámbito de la cooperación judicial, singularmente penal, no responde a un contenido preciso, antes al contrario, conlleva una imprecisión que puede ocasionar muchos problemas habida cuenta de las diferentes sensibilidades en la UE. Por ello debería forzarse a que este concepto sea interpretado a la luz del art. 82.1 TFUE, como integrando un conjunto de normas lo más detalladas posible, del que formen parte siempre las normas relativas a la admisibilidad de las pruebas, los derechos de la persona encausada, los derechos de las víctimas (Marcolini, 2014: 99-108).

${ }^{104}$ Considerando (32) de la Directiva 2010/64/UE. 
La directiva contiene expresiones y conceptos susceptibles de interpretación, cuyo contenido puede ir concretándose a diversos niveles en virtud de la cláusula de no regresión ${ }^{105}$. Una aplicación de esta cláusula puede tener lugar a la hora de definir qué son «documentos esenciales». Fuera de los documentos expresamente mencionados en las normas (decisión por la que se priva a una persona de libertad, escrito de acusación, sentencia y OED), se deja en manos de las autoridades competentes la determinación del carácter esencial de un documento. Esta facultad, además de servir para modular el ámbito de aplicación de la directiva desde un punto de vista material, desvela la eficacia de la cláusula de no regresión para poner bajo el foco la verdadera voluntad de los Estados miembros en relación con los derechos consagrados en la directiva, es decir, su verdadero grado de compromiso.

6) La llegada a la Unión Europea de democracias jóvenes procedentes del este de Europa suscitó recelos y sus sistemas de garantías relativamente recientes provocaron dudas importantes en países con Estados de derecho más consolidados, por ello el estándar de garantías comunes tiene que alcanzar un nivel que permita a estos últimos países alcanzar la confianza necesaria. Se ha afirmado que la aprobación de una regulación común en esta materia planteó dificultades (Irurzun Montoro, 2007: 20-30 $)^{106}$, presumiendo que las exigencias que para algunos Estados son ineludibles pueden suponer un excesivo esfuerzo para otros. Sin embargo, la práctica ha demostrado que esta prevención era excesiva, pues han implementado la directiva incluso aquellos Estados obligados a realizar cambios sustantivos en su legislación ${ }^{107}$. Está claro que todos los Estados

105 Art. 8 Directiva 2010/64/UE: «Ninguna disposición de la presente Directiva se interpretará en el sentido de que limita o deroga cualquier derecho o garantía procesal que pueda existir al amparo del CEDH y de la CDFUE, de otras disposiciones pertinentes del derecho internacional o del ordenamiento jurídico de cualquier Estado miembro que proporcionen un nivel de protección más elevado».

106 Irurzun Montoro puso entonces de manifiesto estas dificultades y reticencias, que colocaron a los Estados miembros en tres posiciones distintas durante las negociaciones: los abiertamente partidarios de una armonización procesal legislativa (Alemania); los que habían constatado que no era posible profundizar sin una previa aproximación legislativa (Suecia, también Francia, aunque por motivos más bien políticos); y aquellos que proponían simples medidas prácticas de apoyo pero que no consideraban oportuna acción legislativa comunitaria alguna (Reino Unido, Irlanda, Polonia).

107 El informe TRAINAC, del CCBE (2016) aclara que han tenido que realizar cambios sustantivos Austria, Bulgaria, Estonia, Francia, Grecia, Italia, Letonia, Polonia, Eslovaquia, Eslovenia, España, Suecia, Países Bajos y Reino Unido (incluida Escocia); 
han tenido presente en el momento de decidir que sus nacionales pueden verse inmersos en procesos penales en cualquier otro Estado miembro, y aspiran a que tengan los mismos derechos procesales que su ordenamiento nacional reconoce a los no nacionales. Entre estas normas mínimas, y por ello inderogables (Faggiani, 2017: 198), la directiva impone la armonización en dos puntos concretos: todos los Estados han de garantizar que en sus ordenamientos exista un procedimiento interno para verificar la necesidad de asistencia lingüística, o no; y asimismo un procedimiento interno para reclamar contra una decisión denegatoria del derecho (Capdepon y Rousseau, 2016: 399). Esto último se introduce expresamente en el art. 125.2 LECrim tras la reforma operada por la LO 5/2015, si bien no concreta el recurso ("podrá interponerse recurso — contra la "decisión" del tribunal- de conformidad con lo dispuesto en esta ley»).

7) Resulta de especial interés el análisis prospectivo que plantean Capdepon y Rousseau (2016: 400) extendiendo el derecho a intérprete y a traducción al propio derecho penal material. Admitido que la legitimidad del derecho del Estado de penar deriva del principio de legalidad y de la presunción de conocimiento de la ley por los ciudadanos, cabe preguntarse si la legitimación de imponer una sanción penal a un ciudadano de otro Estado miembro no deriva también necesariamente de la presunción de que dicho ciudadano no nacional entiende efectivamente el derecho penal del Estado donde está siendo procesado.

Y por lo mismo también cabe extender el reconocimiento efecti$v^{108}$ de estos derechos a los reos que están cumpliendo condena, puesto que es función jurisdiccional no solo el juzgar, sino también el ejecutar lo juzgado, y porque el derecho a entender los derechos que les asisten mientras cumplen la condena (tanto penitenciarios como de amparo ante el juez de vigilancia penitenciaria) forma parte del más amplio derecho a la tutela judicial efectiva consagrado en el art. 47 de la CDFUE, y en el art. 24 de nuestra Constitución (Cámara Arroyo, 2017) ${ }^{109}$.

que simplemente han tenido que realizar cambios menores Chipre, República Checa y Malta; que no han tenido que realizar ningún cambio Croacia, Hungría, Irlanda, Lituania y Portugal. Todavía no la ha implementado Bélgica.

108 Porque nominalmente ya está reconocido en el RD 190/1996 de desarrollo de la LO General Penitenciaria 1/1979.

109 El autor amplía los efectos positivos de reconocer a los internos este derecho a otros objetivos como la posibilidad de crear nuevos destinos para los penados formándoles como intérpretes, frente a los riesgos actuales de que sus actuaciones provoquen equívocos y perjuicios, precisamente por su falta de formación en la terminología jurídica. 


\section{Bibliografía}

Alvarez de Neyra Kappler, S. (2018). El derecho a la traducción y a la interpretación en la detención. En M. J. Ariza Colmenarejo (coord.). Traducción, interpretación e información para la tutela judicial efectiva en el proceso penal (pp. 63-68). Valencia: Tirant lo Blanch.

Arangüena Fanego, C. (2011). El derecho a la interpretación y a la traducción en los procesos penales. Comentario a la Directiva 2010/64/UE del Parlamento Europeo y del Consejo, de 20 de octubre de 2010. Revista General de Derecho Europeo, 24, 9.

— (2015). Nuevos avances en la armonización de las garantías procesales en la Unión Europea. En M. I. González Cano (dir.). Cooperación judicial penal en la Unión Europea: reflexiones sobre algunos aspectos de la investigación y el enjuiciamiento en el espacio europeo de justicia penal (pp. 267-316). Valencia: Tirant lo Blanch.

— (2017). Novedades de 2016 en materia de garantías procesales de sospechosos e imputados en procesos penales. En A. Gutiérrez Zarza (coord.). Los retos del Espacio de Libertad, Seguridad y Justicia. Madrid: La Ley.

Armengot Vilaplana, A. (2016). Llamadme imputado, investigado o encausado, como queráis; pero respetad mis garantías. Diario La Ley, 8776.

Blasco Mayor, M. J. y del Pozo Triviño, M. (2015). La interpretación judicial en España en un momento de cambio. MonTI, 7, 9-40.

Calaza López, S. (2016). Sospechosos, investigados, denunciados, querellados, imputados, procesados, acusados, encausados y, al fin... ¿condenados o absueltos? Todo ello sin dilaciones indebidas. Diario La Ley, 8862.

Cámara Arroyo, S. (2017). Lingüística forense y penitenciaria: el intérprete forense en el proceso penal y el intérprete social en el entorno penitenciario. La Ley Penal, 125.

Campaner Muñoz, J. (2017). Problemas derivados de la transposición de la Directiva 2010/64/UE sobre traducción e interpretación. Ponencia presentada en el Congreso Internacional sobre Garantías Procesales de Investigados y Acusados: Situación actual en el Ámbito de la UE, Valladolid 28 y 29 de septiembre de 2017.

Capdepon, Y. y Rousseau, F. (2016). La légitimité du droit de punir face au multilinguisme et à la liberté de circulation des personnes au sein de l'Union Européenne. Revue des Affaires Européennes. Law and European Affairs, 3, 391-405.

Cras, S. y De Matteis, L. (2010). The Directive on the Right to interpretation and translation in criminal proceedings. Eucrim, 4, 153-162.

De Hoyos Sancho, M. (2017). Sobre la necesidad de armonizar las garantías procesales de los sospechosos en la Unión Europea: valoración de la situación actual y algunas propuestas. Revista General de Derecho Procesal, 43, 1.

Faggiani, V. (2017). Los derechos procesales en el Espacio Europeo de Justicia Penal. Técnicas de armonización. Cizur Menor: Thomson Reuters Aranzadi. 
Fernández Carrón, C. (2017). El derecho a interpretación y a traducción en los procesos penales. Valencia: Tirant lo Blanch.

FRA (Fundamental Rights Agency). (2016). Rights of suspected and accused persons across the EU: translation, interpretation and information. Luxemburgo: FRA.

Gardete, J. M. (2016). Éloge et illustration du multilinguisme. En quoi le multilinguisme participe-t-il de la protection juridictionnelle en droit de l'Union? Revue des Affaires Européennes.Law and European Affairs, 3, 345-354.

Gomez Orbaneja, E. (1981). Derecho Procesal penal. Madrid: Artes Gráficas y Ediciones.

Guerrero Palomares, S. (2016). El derecho a la traducción e interpretación en el proceso penal. Análisis de los nuevos artículos 123 a 127 de la LECRIM, tras la reforma operada por la LO 5/2015 de 27 de abril. Revista Aranzadi de Derecho y Proceso penal, 41, 23-58.

Irurzun Montoro, F. (2007). La negociación de la Decisión Marco sobre garantías procesales en el Consejo de la Unión Europea. En C. Arangüena Fanego (coord.). Garantías procesales en los procesos penales en la Unión Europea (pp. 25-45). Valladolid: Lex Nova.

Jiménez Villarejo, F. (2008). El derecho fundamental a ser asistido por un abogado y por un intérprete. En E. Ortega Arjonilla (dir.). La traducción y la interpretación jurídicas en la Unión Europea. Retos para la Europa de los ciudadanos (pp. 463497). Granada: Comares.

Jimeno Bulnes, M. (2007). Acceso a la interpretación y traducción gratuitas. En C. Arangüena Fanego (coord.). Garantías procesales en los procesos penales en la Unión Europea (pp. 155-183). Valladolid: Lex Nova.

— (2017). La orden europea de detención y entrega: análisis normativo. En C. Arangüena, M. de Hoyos y C. Rodríguez-Medel (dir. y coord.) Reconocimiento mutuo de resoluciones penales en la Unión Europea (pp. 35-76). Cizur Menor: Thomson Reuters Aranzadi.

López Jara, M. (2015). La modificación de la Ley de Enjuiciamiento Criminal en materia de derechos y garantías procesales: los derechos a la traducción e interpretación y a la información en el proceso penal. Diario La Ley, 8540.

Marcolini, S. (2014). The Lisbon Treaty: the Spanish, English and Italian Versions of articles 82-86 of the TFUE in relation to Criminal Justice Cooperation. En F. Ruggieri (ed.). Criminal Proceedings, Languages and European Union. Linguistic and Legal Issues (pp. 99-108). Berlin: Springer.

Ollé Sesé, M. (2016). Derecho de los sospechosos y acusados en procesos penales a interpretación, a traducción y a la información sobre la acusación. STJUE de 15 de octubre de 2015, C-216/2014: Gavril Covaci. La Ley Unión Europea, 35, 8-16.

Pardo Iranzo, V. (2014). La Directiva 2010/64/UE del Parlamento y del Consejo relativa al derecho a interpretación y a traducción en los procesos penales: consideraciones generales. En I. Reig Fabado (coord.). Libertad de circulación, asilo y refugio en la Unión Europea (pp. 385-402). Valencia: Tirant lo Blanch. 
Platon, S. (2016). Multilinguisme et droits fondamentaux en droit de l'Union Européenne. Revue des Affaires Européennes. Law and European Affairs, 3, 429-441.

Portal Manrubia, J. (2016). El derecho a la interpretación y traducción en el proceso penal. Revista Aranzadi Doctrinal, 5, 45-72.

Rojo Chacón, A. (2015). La transposición al derecho nacional de la Directiva Europea 2010/64/UE en España, Francia, Bélgica y Luxemburgo: "Lost in transposition". FITISPos International Journal: Public Service Interpreting and Translation, 2, 94-109.

Ruz Gutiérrez, P. R. (2017). Cuestiones prácticas relativas a la orden europea de detención y entrega. En C. Arangüena, M. de Hoyos y C. Rodríguez-Medel (dir. y coord.). Reconocimiento mutuo de resoluciones penales en la Unión Europea (pp. 77-104). Cizur Menor: Thomson Reuters Aranzadi.

Serrano Masip, M. (2016). Garantías procesales penales específicas reconocidas a menores sospechosos o acusados. En M. Jimeno Bulnes (dir.). Aproximación legislativa versus reconocimiento mutuo en el desarrollo del espacio judicial europeo: una perspectiva multidisciplinar (pp. 209-264). Barcelona: Bosch.

TRAINAC. (2016). Final report: Assessment, good practices and recommendations on the right to interpretation and translation, the right to information and the right of Access to a lawyer in criminal proceedings. Bruxelles: Council of Bars and Law Societies of Europe y European Lawyers Foundation.

Valbuena González, F. (2011). Garantías procesales en la orden de detención europea. En M. Jimeno Bulnes (coord.). Justicia versus seguridad en el espacio judicial europeo. Orden de detención europea y garantías procesales (pp. 201-229). Valencia: Tirant lo Blanch.

Vanden Bosch, Y. (2003). Adequate legislation to "Equal access to Justice across Language and Culture". En Aequalitas. Equal Access to Justice across Language and Culture in de EU. Grotius project 2001/GRP/015. Antwerp: Lessius Hogeschool.

Vidal Fernández, B. (2010). El derecho a intérprete y a la traducción en los procesos penales en la Unión Europea. La iniciativa de 2010 de Directiva del Parlamento Europeo y del Consejo relativa a la interpretación y traducción. En C. Arangüena Fanego (coord.). Espacio de libertad, seguridad y justicia: últimos avances en cooperación judicial penal (pp. 183-222). Valladolid: Lex Nova.

(2007). Derecho a una interpretación y traducción fidedigna y de calidad. Artículos 8 y 9 de la Propuesta de Decisión Marco sobre las garantías procesales de los inculpados en procesos penales en la Unión Europea. En C. Arangüena Fanego (coord.). Garantías procesales en los procesos penales en la Unión Europea (pp. 214-233). Valladolid: Lex Nova.

Vieira Morante, F. J. (2013). La interpretación y traducción de lenguas en los procedimientos judiciales (Directiva 2010/64/UE). Diario La Ley, 8201. 